\title{
Model Penerjemahan Kolaboratif Cerpen "Vertrauen" Melalui Media Online dalam Pembelajaran Penerjemahan
}

\author{
${ }^{1}$ Mochamad Ogi Sandria, ${ }^{2}$ Rosyidah \\ ${ }^{1,2}$ Program Studi Pendidikan Bahasa Jerman, Universitas Negeri Malang \\ Malang, Indonesia
}

Email: ${ }^{1}$ mochamad.ogi.1602416@students.um.ac.id, ${ }^{2}$ rosyidah.fs@um.ac.id

\begin{tabular}{l}
\hline Tersedia Online di \\
\hline http://www.jurnal.unublitar.ac.id/i \\
ndex.php/briliant
\end{tabular}

Sejarah Artikel

Diterima pada 28 September 2020

Disetujui pada 11 Februari 2021

Dipublikasikan pada 28 Februari

2021

Hal. 21-32

\begin{tabular}{l}
\hline Kata Kunci: \\
\hline $\begin{array}{l}\text { Penerjemahan; karya sastra; } \\
\text { kolaboratif; media online; } \\
\text { pembelajaran }\end{array}$ \\
\hline DOI: \\
\hline http://dx.doi.org/10.28926/briliant. \\
v3i4.560
\end{tabular}

\begin{abstract}
Abstrak: Penerjemahan karya sastra merupakan penerjemahan yang kompleks karena melibatkan nilai estetika pada karya sastra, gaya bahasa pengarang, dan unsur budaya. Untuk mengatasi kesulitan-kesulitan dalam penerjemahan karya sastra, penerjemah dapat menerapkan model penerjemahan kolaboratif dengan melibatkan pihak lain, seperti penerjemah lain, pakar di bidang sastra, dan penulis asli dari karya sastra tersebut. Model penerjemahan ini pernah diterapkan oleh dosen dan mahasiswa di kelas penerjemahan Jurusan Sastra Jerman Universitas Negeri Malang yang saling berkolaborasi untuk menerjemahkan cerpen Vertrauen sebagai bahan latihan penerjemahan karya sastra. Cerpen tersebut memiliki beberapa kalimat sulit yang perlu didiskusikan oleh dosen dan mahasiswa agar hasil terjemahan bisa lebih baik dan berterima. Untuk menunjang proses diskusi, dosen dan mahasiswa memanfaatkan media online, yaitu aplikasi Discord.
\end{abstract}

\section{PENDAHULUAN}

Penerjemahan merupakan sebuah aktivitas yang penting untuk dilakukan di era globalisasi saat ini. Melalui penerjemahan, masyarakat bisa mendapatkan informasi dari berbagai belahan dunia. Berkaitan dengan hal tersebut, Shalihah (2017) berpendapat bahwa penerjemahan memiliki peran yang penting dalam menjembatani persoalan yang terjadi karena perbedaan bahasa yang ada di dunia ini. Senada dengan pendapat tersebut, Nerudova (dalam Dağgöl, 2018) menjelaskan bahwa aktivitas penerjemahan di era globalisasi berperan penting dalam membangun pemahaman mutual antarbudaya dan menjadi kunci perekonomian yang penting bagi industri.

Aktivitas penerjemahan saat ini pun menjadi lebih mudah karena banyak berkembang mesin-mesin penerjemah otomatis yang mendukung proses penerjemahan, seperti Google Translate, Systran, dan Bubblefish. Secara tidak langsung, dapat dikatakan bahwa sekarang ini teknologi merupakan bagian yang sangat penting dan menentukan kualitas proses penerjemahan dan hasilnya (terjemahan). Akan tetapi, teknologi tidaklah dapat menggantikan peran penerjemah karena banyak fakta menunjukkan bahwa hasil terjemahan mesin 
belum tentu akurat dan sesuai dengan maksud pengarang teks asli. Berkaitan dengan hal tersebut, teknologi saat ini berperan sebagai fasilitator yang membantu pekerjaan seorang penerjemah (Ivanova, 2016).

Selain mengandalkan bantuan teknologi, penerjemah perlu menggunakan keterampilan dan kreatifitasnya dalam menentukan strategi yang tepat saat menerjemahkan sebuah teks. Penerjemah harus teliti dalam mengidentifikasi jenis teks yang diterjemahkan karena setiap jenis teks memiliki karakteristik yang berbeda-beda, misalnya teks ilmiah yang bersifat formal, teks iklan yang bersifat persuasif, dan teks karya sastra yang bersifat estetis. Puchala (dalam Dağgöl, 2018) menyampaikan bahwa pemahaman yang baik mengenai jenis teks dapat membantu penerjemah dalam menentukan strategi dan pendekatan yang tepat dalam menerjemahkan sebuah teks. Dengan mempelajari jenis-jenis teks yang hendak diterjemahkan, penerjemah dapat lebih mudah memahami sebuah teks dan mengusahakan kesepadanan hasil terjemahan antara bahasa sumber $(\mathrm{BSu})$ dan bahasa sasaran (BSa) (Zheng, 2018).

Apabila dibandingkan dengan jenis teks lain, seperti iklan dan teks ilmiah, karya sastra merupakan salah satu jenis teks yang menjadi tantangan sekaligus kesulitan tersendiri bagi penerjemah. Penerjemah karya sastra dituntut untuk menghasilkan sebuah terjemahan yang dapat memberikan efek yang sama seperti karya aslinya ketika dibaca oleh pembaca BSa (Khrais, 2017). Apabila terjemahan karya sastra itu buruk atau bahkan tidak sesuai dengan karya originalnya, terjemahan tersebut pasti akan menuai kritik dari kalangan penikmat karya sastra. Kritik karya sastra seringkali disampaikan melalui ulasan dalam surat kabar, majalah, dan jurnal dengan tujuan agar pembaca dapat memilah karya sastra terjemahan yang layak dibaca di pasaran (Vandepitte, 2017). Dalam proses pembelajaran di kelas penerjemahan, penelitian Rosyidah, Kharis, dan Lilis (2017) menunjukkan bahwa mahasiswa memerlukan latihan yang lebih banyak untuk dapat meningkatkan kemampuan mereka dalam menerjemahkan karya sastra. Selain itu, mahasiswa perlu membekali diri dengan teori dan prosedur serta teknik dalam penerjemahan karya sastra (Rosyidah, Kharis, dan Afifah, 2017). Oleh sebab itu, penerjemah harus memiliki pengetahuan yang baik tentang dunia sastra dan kemampuan menerjemahkan yang handal dalam penerjemahan karya sastra.

Melihat sulitnya penerjemahan karya sastra, salah satu alternatif solusi yang dapat dilakukan oleh penerjemah adalah dengan cara melakukan kolaborasi dengan pihak lain, khususnya pihak yang berkompeten dalam bidang sastra atau bahkan penulis aslinya, baik secara tatap muka atau secara online dengan bantuan teknologi. Dengan melakukan kolaborasi, penerjemah dapat berkonsultasi mengenai kesulitan-kesulitan yang dihadapi selama menerjemahkan. Penerjemahan kolaboratif bukanlah hal baru dalam praktik penerjemahan, baik dalam dunia akademik maupun di luar dunia akademik. Dalam dunia akademik, Dorri \& Khani (2018) pernah melakukan penelitian yang melibatkan sepuluh mahasiswa yang menempuh studi penerjemahan di Universitas Jahrom dalam proyek penerjemahan secara kolaboratif untuk menerjemahkan teks ilmiah yang dilakukan secara online dengan memanfaatkan media sosial Telegram. Selain itu, Ketola \& GarcíaEscribano (2018) pernah melakukan proyek serupa dalam menerjemahkan berbagai macam jenis teks yang melibatkan pengajar dari delapan universitas di Eropa dan mahasiswa pascasarjana yang menempuh studi penerjemahan dari Universitas 
Tampere \& Universitas Helsinki dengan bantuan media Google + sebagai platform diskusi. Di luar dunia akademik, penerjemahan dengan model ini pernah dilakukan oleh Goethe-Institut Korea dalam sebuah proyek yang bernama Social Translating untuk menerjemahkan karya Thomas Melle yang berjudul Die Welt im Rücken yang saat ini sudah diterjemahkan ke dalam berbagai bahasa. Dalam proyek tersebut, Goethe-Institut Korea mengundang penerjemah dari berbagai wilayah di Asia ke dalam sebuah forum diskusi dan berkomunikasi langsung dengan penulis aslinya (Goethe-Institut Korea, 2018).

Dalam lingkup pembelajaran di Jurusan Sastra Jerman Universitas Negeri Malang, mahasiswa yang menempuh mata kuliah Übersetzung (mata kuliah peminatan bidang penerjemahan) pernah berkolaborasi dalam menerjemahkan teks karya sastra Jerman yang berupa cerpen berjudul Vertrauen. Mahasiswa dan dosen yang mengampu mata kuliah tersebut saling bertukar ide dan pikiran untuk memecahkan permasalahan yang ditemui selama menerjemahkan karya sastra tersebut untuk menghasilkan terjemahan yang baik dan berterima dengan menggunakan media Discord sebagai penunjang proses diskusi secara online. Selain itu, proses penerjemahan tidak hanya berlangsung di dalam kelas, tetapi juga dilakukan di luar perkuliahan sesuai dengan jadwal yang disepakati bersama. Dari berbagai penjelasan tersebut, penulis merasa bahwa topik mengenai penerjemahan karya sastra secara kolaboratif dan peran media online, khususnya dalam pembelajaran penerjemahan penting untuk dibahas secara lebih lengkap dalam artikel ini.

\section{PEMBAHASAN}

\section{Penerjemahan Karya Sastra dan Kesulitannya Bagi Penerjemah}

Karya sastra merupakan sebuah karya fiksi yang memiliki nilai keindahan dan dapat menghibur pembaca. Selain itu, karya sastra memiliki fungsi estetis yang dapat mengekspresikan ide seorang sastrawan dan di dalamnya terdapat unsurunsur emosional, keindahan ungkapan dan bunyi, serta nuansa yang mengiringinya (Suryawinata dan Hariyanto, 2016). Menurut Hariyanto (2019), penerjemahan karya sastra dapat didefinisikan sebagai proses memproduksi ulang pesan dan makna yang terkandung di dalam karya sastra dengan tetap mempertahankan nilai estetikanya. Oleh sebab itu, penerjemahan karya sastra sangat sulit dan penerjemah karya sastra harus kreatif. Selain itu, penerjemah karya sastra harus memahami latar belakang sosiokultural dalam BSu agar dapat menerjemahkan karya sastra dengan baik (Suryawinata dan Hariyanto, 2016).

Sejak penerjemahan karya sastra dipandang sebagai sebuah seni, penerjemahan karya sastra harus merefleksikan imajinasi, intelektual, dan intuisi dari penulis asli. Dalam hal ini, penerjemah karya sastra tidak bisa terlalu setia atau terlalu bebas. Penerjemahan yang terlalu setia terhadap BSu akan berdampak pada kualitas keterbacaan dan kemenarikan cerita, sementara penerjemahan yang terlalu bebas akan membuat terjemahan seperti cerita adaptasi. Oleh sebab itu, penerjemah yang kreatif adalah penerjemah yang tidak menghancurkan identitas asli dari penulis teks dan tidak menciptakan terjemahan yang berbeda dari teks aslinya (Chaal, 2019). 
Kesulitan lain yang seringkali harus dihadapi oleh para penerjemah karya sastra adalah masalah yang berkaitan dengan aspek budaya. Robinson (dalam Suryawinata dan Hariyanto, 2016) mengungkapkan bahwa menerjemahkan karya sastra berarti sebuah upaya untuk menjembatani dua kultur yang berbeda dengan bahasa yang berbeda pula. Berkaitan dengan hal tersebut, Khrais (2017) menyatakan bahwa penerjemah tidak akan bisa lari dari kompleksitas perbedaan antarbudaya. Pendapat tersebut didukung oleh Nida (dalam Makki dan Ahmed, 2020) yang menegaskan bahwa beberapa kata atau frasa dalam BSu yang mengekspresikan suatu objek tertentu memiliki hubungan yang sangat erat dengan budaya yang ada pada BSu tersebut dan tidak ada padanan kata yang tepat pada BSa. Permasalahan ini seringkali ditemui penerjemah ketika mereka berhadapan dengan kata-kata yang bermuatan nilai budaya yang dianut oleh komunitas atau daerah tertentu, seperti ritual keagamaan, nama makanan, nama tempat, dan sejenisnya.

Contoh permasalahan yang berkaitan dengan aspek budaya dapat dilihat pada frasa wei $\beta$ wie Schnee yang apabila diterjemahkan secara harfiah ke dalam bahasa Indonesia berarti seputih salju. Hasil terjemahan itu kurang tepat karena salju tidak ada di Indonesia, sehingga terjemahan itu dapat diganti dengan seputih kapas yang lebih dikenal oleh masyarakat Indonesia. Contoh lain adalah kalimat Ich habe Schwein yang apabila diterjemahkan secara harfiah berarti saya memiliki babi. Hasil terjemahan tersebut tidak sepenuhnya tepat dan tergantung dari konteks kalimat karena dalam budaya Jerman kata Schwein memiliki makna keberuntungan. Jadi, kalimat tersebut dapat diartikan saya beruntung. Selain itu, kata-kata yang hanya terdapat dalam kultur masyarakat Indonesia, seperti upacara ngaben, grebeg suro, genduri, sate, gado-gado, dan sejenisnya, tidak memiliki padanan kata yang tepat ketika diterjemahkan ke dalam bahasa Jerman atau bahasa lainnya. Untuk menerjemahkan kata-kata tersebut, penerjemah biasanya menggunakan catatan kaki yang berisi penjelasan lebih lanjut mengenai makna kata tersebut agar bisa dimengerti oleh pembaca.

Permasalahan lain dalam penerjemahan karya sastra dapat dilihat dalam kutipan berikut ini Donnerwetter, die Kleine ist doch noch viel hübscher als ich gedacht habe. Kata Donnerwetter pada kalimat itu apabila diterjemahkan secara harfiah adalah hujan badai. Namun, terjemahan tersebut tidak tepat karena kata tersebut menyatakan sebuah rasa takjub. Kalimat tersebut bila diterjemahkan dalam bahasa Indonesia berarti Astaga, gadis kecil itu ternyata jauh lebih cantik dari yang kukira. Perbedaan ungkapan/ekspresi yang terdapat dalam BSu dan BSa seperti pada contoh tersebut menuntut penerjemah untuk mencari padanan kata yang tepat dan sesuai agar dapat menciptakan efek yang sama ketika dibaca.

Kerumitan-kerumitan yang terdapat dalam karya sastra membuat proses penerjemahan karya sastra menjadi tantangan tersendiri bagi penerjemah. Oleh sebab itu, Nida dan Savory (dalam Suryawinata dan Hariyanto, 2016) menjelaskan bahwa penerjemah karya sastra harus memiliki syarat-syarat khusus, yaitu sebagai berikut: 1) mampu memahami BSu dengan hampir sempurna; 2) menguasai BSa dengan baik, benar, dan efektif; 3) memiliki pengetahuan yang baik tentang sastra, apresiasi sastra, dan teori penerjemahan; 4) memiliki sensibilitas terhadap karya sastra; 5) memiliki keluwesan kognitif dan keluwesan sosiokultural; dan 6) mempunyai keuletan dan motivasi yang kuat. Dengan bekal kemampuan tersebut, 
seorang penerjemah karya sastra akan mampu menghasilkan terjemahan yang bagus dan berkualitas.

Menurut Nida (dalam Dağgöl, 2018), sebuah terjemahan dapat dikatakan baik apabila terjemahan tersebut mudah dimengerti, mampu menyampaikan pesan yang sama seperti teks aslinya, diekspresikan secara alami, mampu memberikan respon yang sama terhadap pembaca, dan sebisa mungkin tetap menempatkan makna sebagai prioritas utama. Hal tersebut tentu menjadi tantangan bagi seorang penerjemah karena penerjemah harus mampu menyampaikan pesan dan tujuan dari teks BSu ke dalam teks BSa serta membuat hasil terjemahan tersebut ekuivalen atau sepadan dengan teks aslinya. Oleh sebab itu, penerjemah dituntut memiliki keterampilan dan kreatifitas yang tinggi dalam menerjemahkan sebuah teks karya sastra supaya hasil terjemahan sesuai dengan ekspektasi pembaca.

Berdasarkan paparan di atas, penerjemahan karya sastra merupakan pekerjaan yang tidak mudah bagi penerjemah. Penerjemah perlu memiliki pengetahuan yang baik tentang karya sastra, sehingga penerjemah dapat menerjemahkan teks karya sastra dengan baik agar pesan dan isi yang terkandung dalam karya sastra tersampaikan kepada pembaca. Selain itu, penerjemah dapat menerapkan cara lain sebagai solusi untuk mengatasi permasalahan yang terkandung dalam penerjemahan karya sastra, contohnya adalah berkolaborasi dengan pihak lain yang berkompeten dalam bidang sastra atau penulis aslinya langsung.

\section{Konsep Penerjemahan Kolaboratif}

Secara umum, definisi penerjemahan kolaboratif menurut O'Brien (dalam Thelen, 2016) adalah penerjemahan yang melibatkan dua agen perusahaan atau lebih untuk memproduksi sebuah terjemahan atau juga bisa didefinisikan sebagai penerjemahan yang melibatkan dua penerjemah atau lebih yang bekerja sama untuk menghasilkan sebuah produk terjemahan. Pendapat lain diungkapkan oleh Huss (2018) yang menjelaskan bahwa penerjemahan kolaboratif adalah penerjemahan yang melibatkan berbagai pihak, seperti penerjemah dengan penulis asli, dua penerjemah atau lebih yang saling bekerja sama, penerjemah yang bekerja sama dengan penulis naskah, sutradara, aktor, dan agen lainnya, dan juga penerjemah crowdsourcing yang biasanya memanfaatkan teknologi. Berdasarkan berbagai pendapat tersebut, dapat dikatakan bahwa penerjemahan kolaboratif dapat dilakukan secara langsung face-to-face atau secara online dengan memanfaatkan bantuan teknologi komunikasi.

Definisi yang berbeda mengenai penerjemahan kolaboratif juga dikemukakan oleh Gotehe-Institut Korea (2018) yang menyebut model penerjemahan ini dengan istilah social translating. Berdasarkan informasi dari Goethe-Institut Korea, social translating adalah penerjemahan yang melibatkan penerjemah dari berbagai tempat untuk berdiskusi dalam sebuah forum digital dan memungkinkan penerjemah untuk mengundang penulis asli teks atau buku yang sedang diterjemahkan. Dari definisi tersebut, teknologi komunikasi memiliki peranan yang penting dalam proses penerjemahan kolaboratif karena penerjemahan dapat dilakukan secara online dan memungkinkan penerjemah dari berbagai daerah atau negara berkolaborasi bersama. 
Dalam konteks pembelajaran di dalam kelas, penerjemahan kolaboratif berkaitan erat dengan pendekatan konstruktivis sosial dan model pembelajaran kolaboratif (Birkan-Baydan dan Karadag, 2014; Thelen, 2016; Ketola dan GarcíaEscribano, 2018). Vygotsky (dalam Ketola dan García-Escribano, 2018) menjelaskan bahwa pendekatan konstruktivis sosial dalam pembelajaran menekankan konstruksi pengetahuan pembelajar berdasarkan pengalaman sosial yang didapatkan melalui interaksi yang terjadi dalam komunitas/kelompok selama proses pembelajaran. Melalui pendekatan ini, Kiraly (dalam Thelen, 2016) menjelaskan bahwa kompetensi penerjemah dapat terlatih dan terlihat melalui kerjasama yang terjadi dalam sebuah grup dengan cara berkolaborasi.

Thelen (2016) mengungkapkan ciri-ciri penerjemahan kolaboratif dalam pembelajaran penerjemahan dengan lebih rinci sebagai berikut: 1) bertujuan untuk menyelesaikan sebuah tugas atau proyek; 2) terdapat banyak partisipan yang berinteraksi, baik secara syncrhonous maupun asynchronous; 3) terdapat proses negosiasi atau diskusi di antara partisipan; 4) memungkinkan pembagian tugas: 5) dapat didesentralisasi dan bisa juga diorganisasikan sendiri, tetapi hal ini bersifat opsional; dan 6) membutuhkan kesepakatan bersama di antara partisipan. Dari pendapat tersebut, penerjemahan kolaboratif melibatkan kerja sama dan komunikasi yang baik antara partisipan dengan tujuan menyelesaikan tugas secara bersama-sama dan tidak terpisah-pisah.

Dalam pembelajaran penerjemahan, mahasiswa seringkali mengalami kesulitan dalam menerjemahkan teks secara individu karena mereka tidak dapat bertanya apabila menemukan sebuah kata yang sulit, seperti kata yang bermuatan budaya atau kata yang mengandung makna khusus yang hanya dipahami oleh pengarang teks asli (Hartono, 2019). Hal ini berdampak pada hasil penerjemahan secara individu yang kurang akurat dan berterima. Oleh sebab itulah, model penerjemahan kolaboratif dapat dijadikan alternatif solusi untuk mengatasi kesulitan-kesulitan mahasiswa pada saat menerjemahkan sebuah teks.

Dengan menerapkan model penerjemahan kolaboratif di dalam kelas penerjemahan, mahasiswa dapat saling berkolaborasi baik antarmahasiswa maupun dengan dosen yang mengajar dalam penerjemahan berbagai macam teks sebagai bentuk latihan, seperti teks ilmiah, teks karya sastra, dan lain-lain. Pembelajaran penerjemahan kolaboratif tidak bersifat teacher-centered, karena seperti yang disampaikan oleh Birkan-Baydan dan Karadag (2014), dalam pembelajaran kolaboratif pengajar berperan sebagai fasilitator yang memandu aktivitas pembelajaran. Dalam hal ini, mahasiswalah yang berperan aktif dalam berkolaborasi dan menyampaikan ide di dalam grup mereka, sementara dosen dapat memberi masukan apabila mahasiswa mengalami kesulitan dan membutuhkan bantuan.

\section{Peran dan Jenis Media Online dalam Penerjemahan Kolaboratif}

Dalam penerjemahan, khususnya dalam industri penerjemahan, media online memiliki peran yang penting- Keberadaan artificial intelligence/kecerdasan buatan dan media sosial telah mempengaruhi hubungan manusia dalam berkomunikasi dan hal ini berdampak terhadap dunia penerjemahan (Valero-Garcés and Corrochano, 2018). Hal ini menunjukkan bahwa selain mengandalkan mesin penerjemahan, penerjemah seharusnya memanfaatkan media online sebagai alat 
komunikasi dengan baik, seperti media sosial atau platform lain yang serupa. Media online tersebut dapat menjadi fasilitator yang memungkinkan penerjemah dari berbagai tempat untuk saling terhubung dan berdiskusi seputar penerjemahan.

Sebagai fasilitator atau alat bantu yang dapat meringankan pekerjaan penerjemah, teknologi, dalam hal ini mesin-mesin penerjemahan sudah sepatutnya dimanfaatkan dan diikuti terus perkembangannya oleh para penerjemah. Oleh karena itu, keterampilan menggunakan berbagai perangkat teknologi penerjemahan merupakan keterampilan praktis yang wajib dimiliki oleh penerjemah. Menurut Machali (2009) seorang penerjemah yang handal memiliki keterampilan menggunakan dua perangkat utama sebagai modal dasar, yaitu perangkat intelektual dan perangkat praktis. Perangkat intelektual berkaitan erat dengan kompetensi seorang penerjemah dalam penguasaan BSu dan bahasa BSa serta penguasaan teori dan keterampilan dalam menerjemahkan, sedangkan perangkat praktis adalah kemampuan penerjemah dalam memanfaatkan kamus serta sumber referensi lain dalam mencari padanan kata atau istilah yang tepat. Kedua perangkat ini harus dikuasai oleh seorang penerjemah agar teks terjemahan yang dihasilkan berkualitas.

Dalam proses pembelajaran penerjemahan, kedua perangkat tersebut penting untuk dikuasai oleh mahasiswa dalam menerjemahkan sebuah teks. Selain berbekal teori penerjemahan yang sudah dipelajari, mahasiswa dapat memanfaatkan mesin penerjemahan dan media online sebagai alat penunjang proses pembelajaran dalam menerjemahkan teks baik di dalam maupun di luar kelas. Mahasiswa dan dosen dapat saling berkomunikasi dan bertukar pikiran dengan menggunakan media online serta memanfaatkan fitur-fitur yang terdapat pada media tersebut.

Ada beberapa jenis media online yang dapat digunakan sebagai platform diskusi dalam penerjemahan kolaboratif. Olvera-Lobo dan Gutiérrez-Artacho (2014) merekomendasikan media online berikut ini.

\section{Collaborative Work Platform}

Collaborative work platform merupakan platform yang dirancang khusus untuk para pengguna agar dapat berkolaborasi dalam mengerjakan sebuah proyek tertentu. Platform ini dapat digunakan dalam pembelajaran penerjemahan yang memungkinkan dosen dan mahasiswa untuk saling mengunggah hasil terjemahan, bertukar pendapat, memberikan komentar, dan membagi data melalui fitur yang terdapat di dalamnya. Contoh dari platform ini adalah BSCW (Basic Support for Cooperative Work), Claroline, SWAD (Sistema Web de Apoyo a la Docencie), dan Moodle (Olvera-Lobo and Gutiérrez-Artacho, 2014)

2. Teknologi Web 2.0

Web 2.0 adalah istilah yang digunakan untuk menyebut teknologi modern yang memungkinkan penggunanya untuk saling berbagi informasi secara online. Olvera-Lobo and Gutiérrez-Artacho (2014) menjelaskan bahwa teknologi web 2.0 yang dapat digunakan dalam pembelajaran penerjemahan adalah media sosial, wikipedia, dan blog. Ketiga media itu dapat dijadikan media yang menunjang interaksi antara mahasiswa dan dosen dalam pembelajaran penerjemahan. Berkaitan dengan hal tersebut, penulis lebih cenderung memilih media sosial sebagai media yang cocok digunakan dalam penerjemahan kolaboratif. 
Media sosial dapat membuat pengguna dari berbagai wilayah terkoneksi dalam satu waktu. Selain itu, media sosial memiliki fitur-fitur yang menarik, seperti fitur pembuatan grup yang membuat penggunanya dapat saling bertukar informasi dan berdiskusi dalam satu forum yang sama. Pengguna media sosial juga dapat membagikan data lain, seperti gambar, audio, dan video. Contoh media sosial yang dapat digunakan dalam penerjemahan kolaboratif adalah Facebook, Telegram, Discord, dan sejenisnya. Keuntungan terbesar penggunaan media sosial dalam pembelajaran online adalah media sosial mampu mendorong keterlibatan mahasiswa dan menstimulus diskusi antarmahasiswa (Ketola and GarcíaEscribano, 2018).

Berdasarkan penjelasan di atas, media online dalam penerjemahan kolaboratif memiliki peran dalam mempertemukan penerjemah dalam sebuah forum diskusi. Selain itu, media online dapat menjadi penunjang proses pembelajaran di dalam dan di luar kelas sehingga proses pembelajaran lebih fleksibel.

\section{Model Penerjemahan Kolaboratif dalam Penerjemahan Cerpen Vertrauen Melalui Media Online}

Dari berbagai penjelasan sebelumnya, model penerjemahan kolaboratif dengan menggunakan media online menjadi salah satu alternatif yang dapat ditempuh oleh penerjemah dalam menerjemahkan teks karya sastra, baik dalam kegiatan akademik maupun dalam dunia kerja. Untuk menghasilkan terjemahan karya sastra yang bagus, penerjemah perlu melibatkan berbagai pihak terkait, seperti penerjemah lain, pakar dalam bidang sastra, dan penulis asli dari teks yang sedang diterjemahkan apabila memungkinkan. Dengan memanfaatkan media online, penerjemah tidak perlu bertemu secara langsung dalam berkolaborasi dengan pihak lain karena mereka bisa berdiskusi secara online dan mencari solusi atas permasalahan yang sedang dihadapi bersama-sama. Media online yang digunakan dapat ditentukan bersama sesuai dengan kesepakatan. Sebagai contoh, Goethe-Institut melalui proyek social translating memanfaatkan Lectory sebagai platform diskusi bagi para penerjemah.

Penerjemahan dengan model semacam ini pernah dilakukan oleh penulis dalam menerjemahkan cerpen berbahasa Jerman yang berjudul Vertrauen di kelas Übersetzung di Jurusan Sastra Jerman, Universitas Negeri Malang dengan menggunakan aplikasi Discord. Pada tahap awal, para mahasiswa membentuk sebuah kelompok dan bergabung dalam grup yang dibuat pada aplikasi Discord. Setelah itu, mahasiswa dan dosen yang mengampu matakuliah tersebut saling berdiskusi dan bertukar pendapat dan informasi untuk memecahkan kesulitankesulitan yang dihadapi ketika menerjemahkan karya sastra tersebut.

Cerpen Vertrauen ditulis oleh Raphael Herzog dan bercerita tentang seorang pemuda yang melakukan perjalanan untuk menemukan sesuatu yang berharga di sebuah tempat yang jauh dari pemukiman. Dalam perjalanan itu, ia bertemu dengan seorang kakek tua yang memintanya untuk pergi ke sebuah gua karena pemuda itu akan mendapatkan sesuatu yang berharga setelah memasuki gua tersebut. Cerpen tersebut memiliki alur cerita yang menarik dan mengandung pesan moral yang berharga tentang kepercayaan. Selain itu, jumlah kata dalam cerpen Vertrauen tidak terlalu banyak, yaitu sekitar 700 kata sehingga penerjemahan 
cerpen tersebut dapat menghemat waktu. Dalam cerpen tersebut, terdapat beberapa kalimat sulit yang membutuhkan diskusi dari mahasiswa dan dosen agar hasil terjemahan cerpen tersebut bisa lebih baik dan berterima serta memiliki nilai estetika ketika dibaca Berdasarkan alasan-alasan itulah, cerpen Vertrauen dipilih sebagai bahan latihan penerjemahan karya sastra secara kolaboratif di kelas Übersetzung.

Contoh kalimat yang sulit untuk diterjemahkan pada karya sastra tersebut adalah kalimat ein junger Mann ist unterwegs, alleine und weit von der nächsten Zivilisation yang diterjemahkan menjadi seorang pemuda yang sendirian sedang dalam perjalanan dan jauh dari pemukiman. Mahasiswa pada awalnya kesulitan mencari padanan makna yang tepat untuk frasa weit von der nächsten Zivilisation. Mereka saling berdiskusi dan menawarkan beberapa alternatif hasil terjemahan yang dirasa tepat. Setelah melalui perdebatan, frasa weit von der nächsten Zivilisation diterjemahkan menjadi jauh dari pemukiman. Selain contoh tersebut, terdapat kalimat lain yang juga sulit untuk diterjemahkan, yaitu denn er hat gehört, dass es in diesem verlassenem Gebiet, Kostbares zu finden geben soll yang diterjemahkan menjadi karena dia telah mendengar bahwa ia harus ke kawasan yang ditinggalkan ini untuk menemukan barang yang berharga. Masalah yang menjadi persoalan dalam kalimat tersebut adalah frasa in diesem verlassenem Gebiet yang membuat mahasiswa kebingungan dalam mencari padanan yang tepat dan mudah untuk dipahami pembaca. Meskipun pada awalnya sulit, frasa tersebut akhirnya bisa diterjemahkan dengan baik setelah mahasiswa mendapatkan arahan dari dosen mengenai makna frasa tersebut. Dengan bekerja secara kolaboratif, penerjemahan cerpen Vertrauen tersebut menjadi lebih mudah bagi mahasiswa. Selain itu, penerjemahan bersifat fleksibel dan dapat dilakukan di luar perkuliahan pada jam yang sudah disepakati bersama.

Penerjemahan kolaboratif dengan memanfaatkan media online dalam praktiknya memiliki kelebihan dan kekurangan. Kelebihan penerjemahan kolaboratif dengan menggunakan media online adalah sebagai berikut: 1) lebih menyenangkan dan meningkatkan motivasi mahasiswa; 2) melatih dan meningkatkan kemampuan mahasiswa dalam menerjemahkan teks; 3) membantu mahasiswa dalam mengatasi kesulitan-kesulitan yang mereka temukan selama proses penerjemahan; 4) pemberian tugas membuat mahasiswa berusaha untuk menjadi penerjemah yang profesional; dan 5) interaksi yang terjadi antara mahasiswa membuat mereka memiliki beragam perspektif dari berbagai pendapat dan komentar teman mereka. Meskipun demikian, penerjemahan dengan model ini juga memiliki kelemahan utama, yaitu kesulitan pemberian feedback oleh dosen sebagai tutor karena pertemuan dilakukan tidak face-to-face, tetapi secara online sehingga memakan banyak waktu (Al-jarf, 2017; Dorri dan Khani, 2018).

Berdasarkan kelebihannya, penerjemahan secara kolaboratif ini memberi peluang solusi yang bagus bagi pembelajaran/perkuliahan penerjemahan karya sastra. Dengan model latihan ini, mahasiswa dapat mengatasi kesulitan-kesulitan dalam menerjemahkan karya sastra sekaligus menambah wawasan mereka tentang penerjemahan berdasarkan variasi ide dan pendapat yang diungkapkan selama proses diskusi. Hasil penerjemahan yang dihasilkan oleh mahasiswa pun lebih baik dan berterima jika dibandingkan dengan menerjemahkan teks secara individu. 
Selain itu, mahasiswa juga dapat meningkatkan kemampuan mereka dalam memanfaatkan teknologi sebagai penunjang proses penerjemahan dan kemampuan berkomunikasi dengan orang lain di dunia virtual.

Terkait dengan kekurangannya, interaksi yang terjadi dalam forum online perlu mendapatkan perhatian khusus agar pembelajaran bisa berhasil. Proses diskusi dan pemberian feedback yang terjadi di dalam forum online di satu sisi dapat meningkatkan ketertarikan dan motivasi mahasiswa serta menambah perspektif baru seputar penerjemahan, tetapi di sisi lain mahasiswa dapat merasa kurang nyaman dan frustasi apabila mendapatkan komentar yang buruk (Ketola and García-Escribano, 2018). Untuk mengatasi hal tersebut, pemberian apresiasi terhadap mahasiswa yang kemampuannya masih kurang diperlukan agar mahasiswa tersebut tidak kehilangan motivasi. Selain itu, fitur video conference atau webcams dapat dimanfaatkan sebagai variasi dalam pembelajaran agar interaksi yang terjadi dalam forum diskusi online menjadi lebih hidup dan membuat proses pertukaran informasi di antara peserta diskusi menjadi lebih mudah (Al-jarf, 2017).

Dari berbagai penjelasan di atas, penerjemahan karya sastra secara kolaboratif dengan menggunakan media online dapat diterapkan dalam proses pembelajaran/perkuliahan penerjemahan. Dengan menerapkan penerjemahan kolaboratif, mahasiswa dapat saling berkolaborasi dan mengatasi kesulitankesulitan yang ditemui selama berlatih menerjemahkan teks karya sastra. Di samping itu, penerjemahan kolaboratif dapat menambah wawasan dan pengalaman baru bagi mahasiswa dalam penerjemahan karya sastra.

\section{KESIMPULAN}

Penerjemahan karya sastra merupakan penerjemahan yang kompleks dan merupakan sebuah tantangan bagi seorang penerjemah. Dalam penerjemahan karya sastra, terdapat beberapa aspek yang perlu diperhatikan karena seringkali menjadi kesulitan dan penghambat bagi penerjemah, seperti gaya bahasa pengarang teks asli, unsur budaya, dan nilai estetika. Untuk mengatasi kesulitan-kesulitan tersebut, penerjemahan kolaboratif dapat menjadi alternatif solusi yang dapat digunakan oleh penerjemah dalam menerjemahkan karya sastra. Dengan melakukan penerjemahan kolaboratif, penerjemah dapat saling berkomunikasi dengan pihak-pihak terkait, seperti penerjemah lain, pakar di bidang sastra, dan penulis karya sastra yang diterjemahkan secara langsung atau dengan memanfaatkan media online sebagai alat untuk berkomunikasi dan berdiskusi dalam sebuah forum digital. Dalam proses pembelajaran di kelas penerjemahan, model penerjemahan kolaboratif dengan bantuan media online merupakan peluang yang bagus bagi mahasiswa dalam menerjemahkan teks/karya sastra, seperti yang diterapkan di kelas Übersetzung dalam menerjemahkan cerpen Vertrauen. Dengan berkolaborasi, mahasiswa dapat bekerja sama dan bertukar pikiran terkait kesulitan-kesulitan yang dialami selama menerjemahkan karya sastra. Selain itu, mahasiswa bisa mendapatkan pengalamanpengalaman baru yang dapat mendorong kreatifitas mereka dalam menyampaikan ide dan pikiran serta melatih kemampuan bekerja sama mereka dalam menerjemahkan teks karya sastra. 


\section{SARAN}

Hasil kajian artikel ini dapat diterapkan dalam proses pembelajaran penerjemahan untuk meningkatkan kompetensi penerjemahan mahasiswa serta membuat pembelajaran lebih bervariasi dan menyenangkan. Selain itu, penerjemahan kolaboratif dengan memanfaatkan media online ini dapat diterapkan pula dalam lingkup dunia kerja, khususnya bagi penerjemah profesional yang sedang mengerjakan proyek terjemahan karya sastra. Bagi peneliti yang memiliki minat dalam bidang penerjemahan, kajian artikel ini dapat dijadikan bahan referensi untuk meneliti lebih lanjut tentang model penerjemahan kolaboratif dengan memanfaatkan media online sebagai platform diskusi.

\section{DAFTAR RUJUKAN}

Al-jarf, R. S. (2017) Exploring Online Collaborative Translator Training in an Online Discussion Forum, Journal of Applied Linguistics and Language Research, 4(4), pp. 147-160. Available at: http://www.jallr.com/index.php/JALLR/article/view/563.

Birkan-Baydan, E. and Karadag, A. B. (2014) Literary translation workshop: Social constructivist approach classroom activities, Procedia - Social and Behavioral Sciences, 152, pp. 984-988. doi: 10.1016/j.sbspro.2014.09.354.

Chaal, H. (2019) Literary Translation Difficulties: Cultural Barriers, in Darir, H. et al. (eds) Literary Translation from Translation to Creativity. Jordan: Modern's Book World, pp. 130-143. Available at: https://www.researchgate.net/publication/332511380_Literary_translatio n_difficulties.

Dağgöl, G. D. (2018) What lies behind good and poor translation from the perspective of translator trainees ?, Issues in Educational Research, 28(4), pp. 884-900. Available at: http://www.iier.org.au/iier28/dislendaggol.pdf.

Dorri, E. R. and Khani, F. (2018) Innovation in Translation Pedagogy Using Online Collaborative Translator Training, Translation Journal, 21(2), p. Available at: https://www.translationjournal.net/April-2018/innovationin-translation-pedagogy-using-online-collaborative-translatortraining.html.

Goethe-Institut Korea (2018) Literary Translation in Digital Era The Social Translating Blog. Available at: https://www.goethe.de/ins/kr/en/kul/sup/sct/blg.html.

Hariyanto, S. (2019) Penerjemahan Prosa Fiksi dan Puisi: Tantangan dan Penyelesaian, JLT - Jurnal Linguistik Terapan, 9(1), pp. 32-40. Available at: http://jlt.polinema.ac.id/index.php/jlt/article/view/98.

Hartono, R. (2019) STUDENT'S RESPONSE ON COLLABORATIVE TRANSLATION MODEL, Advances in Social Science, Education and Humanities Research (ASSEHR), 188, pp. 11-15. Available at: https://www.atlantis-press.com/proceedings/eltlt-18/125910519.

Huss, J. T. (2018) Collaborative translation, in Washbourne, R. K. and Wyke, B. 
Van (eds) The Routledge Handbook of Literary Translation. London: Routledge, pp. 389-406. Available at: https://www.academia.edu/37517705/Collaborative_Translation.

Ivanova, O. (2016) Translation and ICT competence in the globalized world, Procedia - Social and Behavioral Sciences, 231(May), pp. 129-134. doi: 10.1016/j.sbspro.2016.09.081.

Ketola, A. and García-Escribano, A. B. (2018) Social media platforms in translator training Socialising or separating?, trans-kom, 11(2), pp. 183-200. Available at: https://www.trans-kom.eu/bd11nr02/transkom_11_02_03_Ketola_Bolanos_Social.20181220.pdf.

Khrais, S. M. (2017) Literary Translation and Cultural Challenges : JhumpaLahiri ' s The Namesake, International Journal of Comparative Literature \& Translation Studies, 5(1), pp. 80-86. doi: 10.7575/aiac.ijclts.v.5n.1p.80.

Machali, R. (2009) Pedoman Bagi Penerjemah. Bandung: Penerbit Kaifa.

Makki, A. H. A. and Ahmed, M. A. (2020) An Investigation of the Problems Affecting Literary Translation, Journal of Linguistic and Literary Studies, 21(2), pp. 15-21. Available at: http://repository.sustech.edu/handle/123456789/24829.

Olvera-Lobo, M.-D. and Gutiérrez-Artacho, J. (2014) Web 2 . 0 technologies in the translator training WEB 2 . 0 TECHNOLOGIES IN THE TRANSLATOR TRAINING : AULAINT, in Proceedings of EDULEARN14 Conference. Barcelona: IATED Academy, pp. 1562-1569. Available at: https://www.researchgate.net/publication/264064744_Web_20_technolo gies_in_the_translator_training.

Rosyidah, Kharis, M. and Afifah, L. (2017) Back-Translation Technique to Assess the Students Translation of Literary Text, 5(1), pp. 25-28. doi: 10.11648/j.ijll.20170501.14.

Shalihah, S. (2017) Menerjemahkan Bahasa Arab, At-Ta'dib, 12(1), pp. 157-171. doi: http://dx.doi.org/10.21111/at-tadib.v12i1.867 Available.

Suryawinata, Z. and Hariyanto, S. (2016) Translation: Bahasan Teori \& Penuntun Praktis Menerjemahkan (Edisi Revisi). Malang: Media Nusa Creative.

Thelen, M. (2016) Collaborative translation in translator training, Konin Language Studies, 4(3), pp. 253-269. doi: 10.30438/ksj.2016.4.3.2.

Valero-Garcés, C. and Corrochano, C. C. (2018) Approaches to didactics for technologies in translation and interpreting Introduction to the special issue of trans-kom , Part I, trans-kom, 11([2]), pp. 154-161. Available at: https://www.trans-kom.eu/bd11nr02/transkom_11_02_03_Ketola_Bolanos_Social.20181220.pdf.

Vandepitte, S. (2017) Translation product quality: A conceptual analysis, in Quality aspects in institutional transla- tion. Berlin: Language Science Press, pp. 15-29. doi: 10.5281/zenodo.1048180.

Zheng, W. (2018) Exploring Newmark's Communicative Translation and Text Typology, Advances in Social Science, Education and Humanities Research, 185, pp. 628-630. Available at: https://download.atlantispress.com/article/25891688.pdf. 